\title{
ANALYSIS OF NI (II) ION AND DIMETYLGLIOXIME COMPLEX IN USED ADSORBENT
}

\author{
Bosit Hamidov \\ Professor, Doctor of Technical Sciences, \\ Head of "Petrochemistry" laboratory Institute of General and Inorganic Chemistry \\ of the Academy of Sciences of the Republic of Uzbekistan, \\ Uzbekistan, Tashkent \\ Saidakhon Ubaydullayeva \\ Master of Ferghana Polytechnic Institute, \\ Uzbekistan, Ferghana \\ E-mail: murodbek997@gmail.com
}

\section{АНАЛИЗ ИОНА NI (II) И ДИМЕТИЛГЛИОКСИМНОГО КОМПЛЕКСА В ИСПОЛЬЗУЕМОМ АДСОРБЕНТЕ}

\author{
Хамидов Басит Набиевич \\ д-р техн. наук, профессор, заведуюший лабораторией «Нефтехимия» \\ Института общей и неорганической химии Академии наук РУз,
} Республика Узбекистан, г. Ташкент

Убайдуллаева Сайдахон Бахромджон кизи

магистр

Ферганского политехнического института, Республика Узбекистан, Фергана

\begin{abstract}
This paper presents the results of the analysis of the complex of nickel (II) ion with dimethylglyoxime from the adsorbent composition used in the purification of MDEA. The spectral characteristics of the complex on the SF 46 spectrophotometer, the determination of the composition of the complex using the method of isomolar series, the determination of the actual molar extinction coefficient of the complex and the equilibrium constant by Tolmachyov's graphical method are presented on the basis of tables.

\section{АННОТАЦИЯ}

В данной работе представлены результаты анализа комплекса иона никеля (II) с диметилглиоксимом из состава адсорбента, используемого при очистке МДЭА. Спектральные характеристики комплекса на спектрофотометре СФ 46, определение состава комплекса методом изомолярных рядов, определение фактического коэффициента молярной экстинкции комплекса и константы равновесия графическим методом Толмачева представлены на графике. основа таблиц.
\end{abstract}

Keywords: used adsorbent, Ni (II) ion, dimethylglyoxime reagent, sandel sensitivity, quenching coefficient, Tolmachyev graph, pH, buffer solution.

Ключевые слова: использованный адсорбент, ион $\mathrm{Ni}$ (II), диметилглиоксимовый реагент, чувствительность по Санделу, коэффициент тушения, график Толмачева, $\mathrm{pH}$, буферный раствор.

Currently, the production has a significant negative impact on the environment due to the toxic content of the adsorbents used as waste in industrial zones. The methods of analysis of the isolated complex of toxic $\mathrm{Ni}$ (II) ion formed with dimethylglyoxime in the adsorbent used in this paper are described[4]. Absolute loss of this ion from the adsorbent was achieved, and the spectral characteristics of the complex, the method of isomolar series of the composition of the complex, the equilibrium constant were studied [3].
Spectral description

Light absorption spectra were obtained under selected optimal conditions of the complex formed with dimethylglyoxime reagent and $\mathrm{Ni}$ (II).

Process: $2.6 \mathrm{ml}$ of aqueous solution of $0.01 \%$ dimethylglycosime reagent and $5.0 \mathrm{ml}$ of buffer with $\mathrm{pH}=$ 8.0 in a $25 \mathrm{ml}$ volumetric flask, $3.5 \mathrm{ml}$ of a solution of $\mathrm{Ni}$ (II) of $30.0 \mu \mathrm{g} / \mathrm{ml}$. from the solution and diluted with distilled water to the mark of the flask. The absorption spectrum of the resulting complex was measured in a 
quartz cuvette with a light absorption thickness of $1=1.0$ $\mathrm{cm}$ relative to the reference solution, with a spectrophotometer SF-46. The absorption spectrum of the reagent was obtained with respect to distilled water. The results showed that the maximum absorption area of dimethylglyoxime reagent complex with $\mathrm{Ni}$ (II) was located at $\lambda_{\text {comp }}=550 \mathrm{~nm}$, the maximum light absorption area of dimethylglyoxime reagent was observed in the region of shorter spectral waves, $\lambda_{\text {reagent }}=470 \mathrm{~nm}$.
Using the value of the maximum optical density of the complex compound (in the area $1=550 \mathrm{~nm}$ ), the apparent molar extinction coefficient $\left(\mathrm{E}_{\text {off }}\right)$ [1] was determined by the following formula:

$$
\mathrm{E} \text { off }=\frac{A}{C} \cdot \ell(1)
$$

The spectral characteristics of the complex and the reagent are given in Table 1 . The Sendel sensitivity of the method is $0.001 \mathrm{mcg} / \mathrm{cm} 2$. The light absorption is calculated by the following formula [2]:

$$
\text { S.b.s }=\frac{Q * L * 0.0001}{A * 25}
$$

Table 1.

Results of the study of the composition of a complex compound using the method of isomolar series $\left(\mathrm{C}_{\mathrm{Ni2}+}=30 \mathrm{mkg} / \mathrm{ml} \mathrm{C}_{\mathrm{HR}}=2,0446 * 10^{-5} \mathrm{M}, 1=1,0 \mathrm{sm}, \mathrm{n}=3\right)$

\begin{tabular}{|c|c|c|c|c|c|c|c|c|}
\hline $\begin{array}{c}\text { Color of } \\
\text { complex }\end{array}$ & $\mathbf{p H}$ & $\mathbf{C}_{\mathbf{M e R}, \mathbf{n m}}$ & $\mathbf{C}_{\mathbf{H R}}, \mathbf{n m}$ & $\Delta \boldsymbol{\lambda}$ & $\begin{array}{c}\mathbf{C}_{\mathbf{N i}}{ }^{2+}, \\
\mathbf{m k g}\end{array}$ & $\begin{array}{c}\mathbf{C}_{\mathbf{N i}}{ }^{2+}, \\
\mathbf{M o l} / \mathbf{l}\end{array}$ & $\overline{\mathbf{A}}$ & $\begin{array}{c}\text { Sendel sensitivity } \\
\mathbf{M k g} / \mathbf{s m 2}\end{array}$ \\
\hline Red-pink & 8.0 & 550 & 480 & 70 & 30 & $2.0446^{*} 10^{-5}$ & 0.435 & $0,0027586 \mathrm{mkg} / \mathrm{sm} 2$ \\
\hline
\end{tabular}

S.b.s. $=Q \cdot l \cdot 0,001 / A \cdot 25=30,0 \cdot 1,0 \cdot 0,0010,435 \cdot 25,0=0,0027586 \mathrm{mkg} / \mathrm{sm}^{2}$

The results show that the reaction has a high contrast $\left(\right.$ at $\left.1_{\text {comp }}=550 \mathrm{~nm}\right)$ and sensitivity (S.b.s. $=$ 0.0027586).

Determination of the proportion of constituent moles of the complex formed by nickel (II) with dimethylglyoxime reagent. Determination of complex composition using the method of isomolar series.

The molar ratios of the components in the complex formed by nickel (II) with the dimethylglyoxime reagent were determined by the isomolar series method. Equilibrium solutions of nickel (II) and dimethylglyoxime reagents were used to determine the ratio of moles in the complex formed by nickel (II) with dimethylglyoxime reagent by the method of isomolar series: $\mathrm{C}_{\mathrm{Ni} 2+}=\mathrm{C}_{\mathrm{HR}}=2,0446 \cdot 10^{-5} \mathrm{~mol} / \mathrm{l}$

Proccess: A series of solutions were prepared in 25 $\mathrm{ml}$ volumetric flasks. To do this, add to each of a variable amount of nickel (II) solution (up to 9.0-1.0 ml) and add a variable amount of dimethylglyoxime reagent solution (up to $1.0 \mathrm{ml}-9.0 \mathrm{ml}$ ). and $5.0 \mathrm{ml}$ of a universal buffer solution with a $\mathrm{pH}$ of 8 were diluted and mixed with distilled water to the mark of the tube.

The optical density of the prepared solutions was measured at KFK-2 at a light filter at 550nm and relative to the reference solution in cuvettes with a light absorption thickness of $1=1.0 \mathrm{~cm}$. The results obtained are given in Table 2.

Table 2.

Results of the study of the composition of a complex compound using the method of isomolar series

\begin{tabular}{|c|c|c|c|c|}
\hline № & Obtained Ni(II), ml & Obtained VHr, ml & Buffer solution & A \\
\hline 1. & 9.5 & 1.5 & 5.0 & 0.007 \\
\hline 2. & 8.5 & 2.5 & 5.0 & 0.08 \\
\hline 3. & 7.5 & 3.5 & 5.0 & 0.165 \\
\hline 4. & 6.5 & 4.5 & 5.0 & 0.30 \\
\hline 5. & 5.5 & 5.5 & 5.0 & 0.34 \\
\hline 6. & 4.5 & 6.5 & 5.0 & 0.39 \\
\hline 7. & 3.5 & 7.5 & 5.0 & 0.45 \\
\hline 8. & 2.5 & 7.0 & 5.0 & 0.50 \\
\hline 9. & 2.0 & 8.0 & 5.0 & 0.43 \\
\hline 10. & 1.0 & 9.0 & 5.0 & 0.33 \\
\hline
\end{tabular}


It can be seen from this table that the composition of the complex formed by the dimethylglyoxime reagent with Nickel (II) corresponded to the molar ratio of $\mathrm{Ni}: \mathrm{R}=1: 2$.

Determination of the real molar extinction coefficient and equilibrium constant of the complex of nickel (II) with dimethylglyoxime reagent by Tolmachyov's graphical method

For a more detailed study of the complex formation reaction of nickel (II) in the dimethylglyoxime reagent and the adsorbent used, the equilibrium constant of the complex formation was determined by Tolmachyov's graphical method. All the above results (Ni: $\mathrm{R}=1: 2$ ) were taken into account when working with this method. The reaction equation for Ni (II) with dimethylglyoxime reagent can be described as follows.

Proccess: A 25-ml volumetric flask was filled with a stoichiometrically reactive reagent and nickel (II) solution and a $5.0 \mathrm{ml}$ buffer mixture with a $\mathrm{pH}$ of 8.0 and diluted to the mark with distilled water. The optical density was measured at KFK-2 at $6 \mathrm{nf}$, relative to the specific solution in cuvettes with a light absorption thickness of $1=1.0 \mathrm{~cm}$. The results are presented in Table 3.

Table 3.

\section{Results of determination of real molar extinction coefficient and equilibrium constant of the complex by Tolmachyov's graphical method}

\begin{tabular}{|c|c|c|c|c|c|c|c|c|}
\hline № & $\mathbf{V}_{\text {Ni+2, мл }}$ & $\mathbf{V}_{\text {НR, мл }}$ & $\begin{array}{c}\mathbf{C}_{\text {Ni 2+ }} \\
\mathbf{1 0 - 5}\end{array}$ & $\breve{\mathbf{A}}$ & $\sqrt{\breve{A}}$ & $\sqrt[\mathbf{1}]{\breve{A}}$ & $\mathbf{E}$ & $\mathbf{1 / \varepsilon}$ \\
\hline 1. & 0.25 & 0.5 & 0.075 & 0.774 & 3.649 & 1.022 & 7338.5 & 1.36 \\
\hline 2. & 0.50 & 1.5 & 0.100 & 0.316 & 3.164 & 2.044 & 4892.36 & 2.04 \\
\hline 3. & 0.75 & 2.5 & 0.128 & 0.358 & 2.793 & 3.066 & 4174.48 & 2.40 \\
\hline 4. & 1.00 & 3.5 & 0.157 & 0.394 & 2.538 & 4.088 & 3791.58 & 2.64 \\
\hline 5. & 1.25 & 4.5 & 0.160 & 0.400 & 2.590 & 5.11 & 2622.95 & 3.13 \\
\hline 6. & 1.50 & 5.5 & 0.180 & 0.424 & 2.350 & 6.13 & 2517.48 & 3.40 \\
\hline
\end{tabular}

Tolmachyov's graphical formula for the real molar extinction coefficient and equilibrium constant of a complex [2]:

$$
[1 / \varepsilon=\mathrm{f}(1 / \sqrt{ } A)]
$$

The following formulas were used in the calculations:

$$
\varepsilon_{\text {real }}=1 / 1 / \varepsilon \cdot 10^{-n}=1 / 0,136 * 10^{-4}=7,52 * 10^{-4}(4)
$$

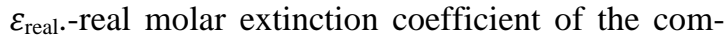
plex;

Compared to the calculated numerical values, the developed method showed a much higher sensitivity, and the complex compound had an average stability.
According to the results obtained, the solution of dimethylglyoxime, used as a reagent in the complete complex precipitation of nickel ions in the adsorbent used, gave good results. According to the spectral characteristics of this complex, the absorption spectrum was measured in a quartz cuvette with a light absorption thickness $1=1.0 \mathrm{~cm}$ relative to the reference solution, with a spectrophotometer SF-46.

The absorption spectrum of the reagent was obtained with respect to distilled water. The results showed that the maximum absorption area of dimethylglyoxime reagent complex with $\mathrm{Ni}$ (II) was located at $\lambda \operatorname{comp}=550 \mathrm{~nm}$, the maximum light absorption area of dimethylglyoxime reagent was observed in the region of shorter spectral waves, $\lambda$ reagent $=470 \mathrm{~nm}$, real molar extinction coefficient of the complex is $7,52 * 10^{-4}$.

\section{References:}

1. Analitik kimyo: Oliy o'quv yurtlarining oziq-ovqat texnologiyasi fakultetlari uchun o'quv qo4./M.T.Gulamova, Sh.Q.Norov, N.T.Turobov; 0'z.R Oliy va o'rta-maxsus ta'lim vazirligi. — T.: «Vorisnashriyot», 2009. - 320 b.

2. Харитонов Ю.Я. Аналитическая химия. ИздательствоГЭОТАР-Медиа ISBN 978-5-9704-2934-1. Год издания 2014

3. Мансурходжаев У.М ,Талипов Ш.Т, Каракулова М.А.Фотометрическое определение никеля.-В кн.Актуалные вопросы химии комплексных соединый .Сб.науч.тр.Ташкент, 1982 ,N:680,C.56-59.

4. Мамадалиева С.В. Зависимость показателей очищаемого парафина от размера гранул применяемого адсорбента // Universum: химия и биология: электрон.научн.журн. $2019 . \quad$ № 11(65). URL:https://7universum.com/ru/nature/archive/item/8079 (дата обращения: 13.05.2021). 